\title{
PENGARUH AKTIVITAS RASIO, UKURAN PERUSAHAAN, STRUKTUR MODAL, LIKUIDITAS DAN DEBT RATIO TERHADAP PROFITABILITAS SUB SEKTOR MAKANAN DAN MINUMAN DI BEI 2009-2016
}

\author{
Ariokunto Pangestu \\ Program Studi Magister Manajemen Universitas Tarumanagara \\ ariokunto.pangestu@gmail.com
}

\begin{abstract}
The purpose of this research is to determine the effect of the ratio of activity, firm size, capital structure, liquidity and debt ratio to company's profitability in manufacturing companies food sub-sector and bevarages listed in Indonesia Stock Exchange. The sampling method is done by using purposive sampling. The method of collecting secondary data is taken from the IDX that publishes the financial statements. This research uses several analytical methods, descriptive statistical analysis, classical assumption test, multiple regression analysis, simultaneous test ( $\mathrm{F}$ test), partial test ( $\mathrm{T}$ test) and determnasi test (adjusted $\mathrm{R}^{2}$ ) to test its hypothesis using Eviews 9. The results showed that total asset turnover of debt equity ratio has a positive significance, size has positive not significant, current ratio has negative ratio is not significant and debt has significant negative effect to profitability of company which measured by using Return Of Equity. F-test results show that all independent variables in this research simultaneously have a significant effect on the return of equity of companies in the food and beverages sub-sector listed on the Indonesia Stock Exchange. In the Adjusted $\mathrm{R}^{2}$ test, the analysis results show that $95.2 \%$ return of equity is influenced by the independent variables of this research while the remaining $4.8 \%$ is influenced by other factors not studied.
\end{abstract}

Keywords : Total Asset Turnover, Size, Debt Equity Ratio, Current Ratio, Debt Ratio and Return Of Equity

\section{PENDAHULUAN}

Pertumbuhan ekonomi dan pembangunan merupakan kondisi yang dapat menunjukkan perkembangan suatu negara. Kondisi persaingan saat ini semakin ketat dalam dunia usaha. Perekonomian yang semakin tidak menentu membuat banyak perusahaan mengalami masalah pendanaan dalam membiayai kegiatan operasionalnya. Banyaknya perusahaan industri, ditambah kondisi perekonomian saat ini menciptakan persaingan antar perusahaan manufaktur. Salah satu upaya untuk mencapai tujuannya, perusahaan selalu berusaha memaksimalkan labanya. Dengan bertambah besarnya perusahaan, maka perusahaan berkembang dapat mengikuti dan memenuhi kebutuhan pasar yang berubah-ubah.

Persaingan dalam dunia usaha, khususnya pada industri manufaktur sub sektor makanan dan minuman, membuat setiap perusahaan semakin meningkatkan kinerjanya agar tujuan perusahaan dapat tercapai. Sub sektor makanan dan minuman mempunyai peran yang penting dalam pembangunan industri manufaktur. Salah satu caranya adalah dengan menjaga laba perusahaannya. Mahalnya biaya bahan baku juga tingginya biaya produksi mengakibatkan harga produk yang dijual semakin tinggi. Jika hal ini terjadi dapat mengakibatkan daya saing produk sub sektor makanan dan minuman semakin rendah dan terpuruk karena produk lebih mahal dari produk perusahaan lainnya.

Perusahaan-perusahaan yang mengalami kerugian dan keuntungan pada tahun 2014. PT. Ultrajaya Milk Industry \& Trading Co Tbk (ULTJ) yang mengalami penurunan laba bersih $26 \%$ pada tahun 2014 diakibatkan biaya pokok penjualan perusahaan yang meningkat menjadi 2,21 $\mathrm{T}$ dari 1,75 $\mathrm{T}$ sehingga laba perusahaan berkurang menjadi 669,93 $\mathrm{M}$ dari $774,71 \mathrm{M}$. Aset perusahaan ULTJ tercatat sebesar 3,04 T dengan total hutang 851,27 M 
meningkat dibanding tahun 2013 dimana aset perusahaan 2,81 T dengan total hutang 796,47 M (J Erna, 2014). PT. Indofood Sukses Makmur, Tbk (INDF) mendapatkan kenaikan laba bersih $90 \%$ pada tahun 2014 diakibatkan penjualan bersih naik $27 \%$ menjadi $16,37 \mathrm{~T}$ dari 12,89 T. Dimana biaya pokok penjualan perusahaan juga meningkat menjadi $12,07 \mathrm{~T}$ dari 9,78 T. Aset perusahaan INDF meningkat menjadi 81,376 T dari 78,09 T (J Erna, 2014).

Dari latar belakang di atas besarnya laba perusahaan dipengaruhi oleh beberapa faktor yang akan diteliti dalam penelitian ini yaitu aktivitas rasio, ukuran perusahaan, struktur modal, likuitditas dan debt ratio. Menurut G.Sugiyarso dan F.Winarni (2005:118) profitabilitas adalah rasio dari efektifitas manajemen berdasarkan hasil pengembalian yang dihasilkan dari penjualan dan investasi. Variabel-variabel rasio profitabilitas terdiri atas profit margin, basic earning power, return on asset, dan return on equity. Dalam penelitian ini rasio profitabilitas diukur dengan return on equity (ROE). Semakin tinggi laba perusahaan maka akan semakin tinggi laba perusahaan (ROE).

Aktivitas rasio atau total asset turnover (TATO) merupakan perbandingan antara penjualan bersih dengan total aktiva dalam perusahaan. Alasan pemilihan rasio ini karena keefektifan perusahaan dalam menghasilkan penjualan dengan menggunakan aktivanya akan ditunjukkan melalui perhitungan TATO (Syamsuddin, 2009: 19). Ukuran perusahaan atau size adalah skala perusahaan yang dilihat dari total aktiva perusahaan pada akhir tahun. Total penjualan juga dapat digunakan untuk mengukur besarnya perusahaan. Karena biaya - biaya yang mengikuti penjualan cenderung lebih besar, maka perusahaan dengan tingkat penjualan yang tinggi cenderung memilih kebijakan akuntansi yang mengurangi laba (Sidharta, 2000). Perusahaan yang memiliki banyak aset akan dapat meningkatkan kapasitas produksi yang berpotensi untuk menghasilkan laba lebih baik. (Stein, 2013) menyebutkan variabel yang terkait dengan pengukuran struktur modal adalah debt equity ratio (DER). Adanya peningkatan hutang akan mempengaruhi risiko dan keuntungan yang diperoleh perusahaan yang diakibatkan dari penggunaan hutang tersebut. Hal ini disebabkan penggunaan hutang mempunyai risiko yang tinggi yaitu biaya modal.

Munawir (2010) Likuiditas dapat diukur dengan menggunakan current ratio. Kemampuan perusahaan untuk memenuhi, membayar, serta melunasi kewajiban finansial jangka pendeknya dengan aktiva lancar. Selain itu, menurut Syamsuddin (2007) debt ratio (DR) atau debt asset ratio (DAR) digunakan untuk mengukur seberapa besar jumlah aktiva perusahaan yang dibiayai dengan total hutang dan mengukur tingkat solvabilitas perusahaan dengan menunjukkan kemampuan perusahaan dalam membayar kewajiban jangka panjang. Berdasarkan latar belakang di atas, didapatkan suatu gambaran tentang adanya pengaruh berbeda-beda yang ditimbulkan oleh aktivitas rasio, ukuran perusahaan dan struktur modal. Oleh karena itu, penulis tertarik untuk melakukan penelitian yang diberi judul "Pengaruh Aktivitas Rasio, Ukuran Perusahaan, Struktur Modal, Likuiditas Dan Debt Ratio Terhadap Profitabilitas Sub Sektor Makanan dan Minuman di BEI 2009-2016”.

\section{TELAAH KEPUSTAKAAN}

\section{Return On Equity (ROE)}

Menurut Sartono (2001) Return on equity (ROE) adalah kemampuan untuk mengukur perusahaan dalam memperoleh laba yang tersedia bagi pemegang saham perusahaan. Secara eksplisit, ROE memperhitungkan kemampuan perusahaan dalam menghasilkan return bagi pemegang saham biasa setelah memperhitungkan bunga (biaya hutang) dan biaya saham preferen. Rasio ini sangat penting bagi pemilik perusahaan (the common stockholder), karena menunjukkan tingkat kembalian yang dihasilkan oleh manajemen dari modal yang disediakan oleh pemilik perusahaan. Dengan kata lain, ROE menunjukkan keuntungan yang akan dinikmati oleh pemilik saham.

\section{Total Asset Turnover}


Menurut Syamsuddin (2009:19) TATO merupakan rasio yang menunjukkan tingkat efisiensi penggunaan keseluruhan aktiva perusahaan dalam menghasilkan volume penjualan tertentu. TATO dipengaruhi oleh jumlah penjualan dan total aktiva, baik aktiva lancar maupun aktiva tetap, karena itu, TATO dapat diperbesar dengan menambah aktiva pada satu sisi dan pada sisi lain diusahakan agar penjualan dapat meningkat relatif lebih besar dari peningkatan aktiva atau dengan mengurangi penjualan disertai dengan pengurangan relatif terhadap aktiva. Semakin besar rasio ini semakin baik yang berarti bahwa aktiva dapat lebih cepat berputar dan meraih laba dan menunjukkan semakin efisien penggunaan keseluruhan aktiva dalam menghasilkan penjualan. Dengan kata lain jumlah aset yang sama juga dapat memperbesar volume penjualan apabila TATO ditingkatkan atau diperbesar. Hal ini menggambarkan adanya pengaruh positif dari TATO terhadap ROE. Teori ini sesuai dengan penelitian Mou Xu dan Wanrapee B. (2015) ; Arif S. (2011) ; Rizki Andriani P. et al (2015) yang menyatakan bahwa TATO berpengaruh positif terhadap ROE.

\section{Size}

Menurut Fahmi (2011:2), semakin baik kualitas laporan keuangan yang disajikan maka akan semakin menyakinkan pihak eksternal dalam melihat kinerja keuangan perusahaan tersebut, yang otomatis tentunya pihak-pihak yang berhubungan dengan perusahaan akan merasa puas dalam berbagai urusan dengan perusahaan. Perusahaan selalu menginginkan perolehan laba bersih setelah pajak karena bersifat menambah modal sendiri. Dengan kata lain, laba bersih dapat diperoleh jika jumlah penjualan lebih besar daripada jumlah biaya operasi. Agar diperoleh laba bersih yang sesuai dengan jumlah yang diinginkan, maka perencanaan dan pengendalian menjadi hal yang sangat penting dilakukan oleh pihak manajemen. Apabila suatu perusahaan asetnya lebih besar dari aset perusahaan lainnya artinya perusahaan tersebut kapasitas produksinya lebih besar. Maka akan lebih berpotensi mendapatkan keuntungan yang lebih baik dan sejumlah asetnya akan maksimum dalam memenuhi permintaan. Jika kondisi ekonomi stabil, tidak ada gejolak dan semua kondisi ideal dengan manajemen yang dapat memanfaatkan asetnya, maka profit dapat meningkat. Hal ini menggambarkan adanya pengaruh positif dari size terhadap ROE. Teori ini sesuai dengan penelitian Arif S. (2011) ; Lukman P. et al (2014) yang menyatakan bahwa ukuran perusahaan berpengaruh positif terhadap ROE

\section{Debt Equity Ratio}

Menurut Munawir (2007:239) DER merupakan perbandingan rasio antara hasil hutang secara keseluruhan dengan modal sendiri yang dimiliki oleh perusahaan. Modal pinjaman dapat berupa hutang jangka pendek maupun hutang jangka panjang, tetapi karena pada umumnya pinjaman jangka panjang jauh lebih besar dibandingkan dengan utang jangka pendek, maka perhatian analis keuangan biasanya lebih menekankan pada jenis hutang ini. Rasio ini menunjukkan hubungan antara jumlah pinjaman jangka panjang yang diberikan oleh para kreditur dengan jumlah modal sendiri yang diberikan oleh pemilik perusahaan. Rasio hutang modal menggambarkan sampai sejauh mana modal pemilik dapat menutupi hutang-hutang kepada pihak luar dan merupakan rasio yang mengukur hingga sejauh mana perusahaan dibiayai dari hutang. DER menggambarkan kemampuan perusahaan dalam mengcover pembayaran hutang jangka panjang dengan menggunakan modal sendiri atau ekuitas dari shareholders. Semakin tinggi hasil DER, maka akan semakin besar kreditur meminjamkan hutang ke perusahaan. Pembelanjaan investasi perusahaan yang dilakukan dengan menggunakan hutang dapat mempengaruhi kemampuan perusahaan dalam menghasilkan laba atas modal yang dimiliki perusahaan. Rasio DER yang tinggi dapat menggambarkan bahwa perusahaan dapat beroperasi dengan hutang sebagai modalnya. Hutang usaha ini jika dipergunakan secara tepat akan dapat menghasilkan profit yang semakin meningkat pula bila dibandingkan dengan operasional dengan modalnya sendiri. Hal ini menggambarkan adanya pengaruh positif dari DER terhadap ROE. Teori ini sesuai 
dengan penelitian Jihan Salim (2015); Ahmad Ali (2015) yang menyatakan bahwa DER berpengaruh positif terhadap ROE

\section{Current Ratio}

Menurut Fahmi (2014:121) Current ratio (CR) adalah ukuran yang umum digunakan dalam hutang jangka pendek, kemampuan suatu perusahaan memenuhi kebutuhan hutang ketika jatuh tempo. Semakin tinggi CR maka perusahaan dianggap memiliki kemampuan untuk melunasi atau menutupi kewajiban jangka pendeknya kepada pihak kreditur. CR yang baik membuat perusahaan dalam menghasilkan laba sangat efektif karena para investor percaya untuk berinvestasi pada perusahaan. Semakin tinggi CR suatu perusahaan berarti semakin kecil resiko kegagalan perusahaan dalam memenuhi kewajiban jangka pendeknya. Akibatnya resiko yang ditanggung pemegang saham juga semakin kecil. Nilai CR yang tinggi dari suatu perusahaan akan mengurangi ketidakpastian bagi investor. Hal ini menggambarkan adanya pengaruh positif dari CR terhadap ROE. Hal ini sejalan dengan penelitian Mou Xu dan Wanrapee B. (2015) ; Septy Wulan S. (2017) yang menyatakan CR berpengaruh positif terhadap profitabilitas

\section{Debt Ratio}

Menurut Syamsuddin (2009) Debt ratio (DR) atau debt asset ratio (DAR) merupakan rasio yang mengukur tingkat penggunaan hutang terhadap total aktiva yang dimiliki perusahaan. Rasio ini mengukur seberapa besar aktiva perusahaan yang dibiayai oleh kreditur. Semakin tinggi DR semakin besar jumlah modal pinjaman yang digunakan dalam menghasilakn keuntungan bagi perusahan. Selain itu, rasio ini juga menunjukkan besarnya total hutang terhadap keseluruhan total aktiva yang dimiliki oleh perusahaan dan merupakan persentase dana yang diberikan oleh kreditur bagi perusahaan. Utang yang digunakan kelebihannya yaitu bunga yang dibayarkan merupakan pengurang pajak dan perusahaan yang menggunakan utang dan keuntungannya lebih besar dari biaya tetapnya, maka perusahaan akan mendapatkan keuntungan. Semakin tinggi nilai DR maka perusahaan akan mendapatkan ROE yang semakin tinggi. Di sisi lain, perusahaan yang menggunakan hutang dalam jumlah besar umumnya memiliki ROE tinggi, karena manajemen berusaha untuk mewujudkan tingkat pengembalian yang disyaratkan oleh investor akibat tingginya risiko. Selain itu hutang yang besar menimbulkan perlindungan pajak karena laba operasi dikurangkan terlebih dahulu dengan beban bunga sehingga ROE pun tinggi. Hal ini disebabkan laba setelah pajak dibandingkan dengan ekuitas yang jumlahnya lebih kecil dari hutang. Selain itu perusahaan juga dapat memanfaatkan keuntungan dari perlindungan pajak untuk meningkatkan kegiatan operasionalnya dengan menggunakan aktivanya secara efektif. Hal ini menggambarkan adanya pengaruh positif dari CR terhadap ROE. Hal ini sejalan dengan penelitian yang dilakukan oleh Tariku Negasa (2016) ; Faizatur Rosyadah et al (2013) yang menyatakan debt ratio berpengaruh positif terhadap profitabilitas.

\section{HIPOTESIS PENELITIAN}

Hipotesis dalam penelitian ini adalah sebagai berikut :

$\mathrm{H}_{1} \quad$ : Terdapat pengaruh yang signifikan antara aktivitas rasio, ukuran perusahaan, stuktur modal, likuiditas dan debt ratio secara bersamaan terhadap profitabilitas pada perusahaan manufaktur sub sektor makanan dan minuman yang terdaftar dalam Bursa Efek Indonesia.

$\mathrm{H}_{2}-\mathrm{H}_{6}$ : Terdapat pengaruh yang signifikan antara masing-masing variabel bebas yaitu, aktivitas rasio, ukuran perusahaan, struktur modal, likuiditas dan debt ratio terhadap variabel terikat profitabilitas pada perusahaan manufaktur sub sektor makanan dan minuman yang terdaftar dalam Bursa Efek Indonesia.

\section{METODOLOGI PENELITIAN}


Jenis data yang digunakan dalam penelitian ini adalah data kuantitatif. Populasi dalam penelitian ini adalah seluruh perusahaan manufaktur sub sektor makanan terdaftar dalam Bursa Efek Indonesia (BEI). Metode dalam pemilihan sampel dilakukan berdasarkan metode Purposive Sampling. Beberapa kriteria yang ditetapkan untuk memperoleh sampel perusahaan sampel menerbitkan laporan keuangan selama 8 tahun periode 2009 - 2016. Dari kriteria-kriteria tersebut diperoleh subyek penelitian sebanyak 10 perusahaan. Teknik analisis data menggunakan analisis linier berganda. Berikan model atau persamaannnya

Data yang diperoleh diolah dan dianalisis dengan menggunakan metode pengolahan data elektronik, yaitu dengan menggunakan software Eviews 9.

\section{HASIL DAN PEMBAHASAN}

\section{Hasil Analisis Regresi Linear Berganda}

Analisis regresi variabel dependen dan independen ini menggunakan Eviews 9 yang hasilnya dapat dilihat pada Tabel 1:

Berdasarkan Tabel 1 dapat dibuat persamaan linier berganda sebagai berikut :

$\mathrm{Y}=-0.319349+0.077996 \mathrm{AKT}+0.070933 \mathrm{SIZE}+0.385161 \mathrm{DER}-0.011331 \mathrm{CR}-$ $1.675496 \mathrm{DR}+0.860926$

Keterangan :

$\mathrm{Y} \quad=$ Profitabilitas

AKT = Aktivitas Rasio (total asset turnover)

SIZE = Ukuran Perusahaan

$\mathrm{DER}=$ Struktur Modal (debt equity ratio)

$\mathrm{CR} \quad=$ Likuiditas (current ratio)

$\mathrm{DR}=$ Debt ratio

\section{PEMBAHASAN}

Persamaan linier berganda di atas memiliki pengertian bahwa ROE akan bernilai 0.541577 satuan yaitu -0.319349 ditambah dengan 0.860926 yaitu besarnya faktor-faktor lain diluar variabel independen yang diajukan dalam penelitian ini atau konstanta dan error dalam persamaan regresi jika variabel independennya sama dengan nol) jika variabel dependen dianggap tidak ada atau nol. Dari persamaan di atas juga dapat diartikan untuk variabel pertama yaitu aktivitas rasio yang diproksikan dengan total asset turnover yang dimiliki oleh perusahaan secara parsial pada 10 perusahaan dalam waktu 8 tahun akan mempengaruhi ROE secara positif sebesar koefisiennya. Jika terjadi kenaikan satu satuan pada TATO dan variabel independen lainnya dianggap konstan, maka ROE akan naik sebesar 0.077996 satuan. Selanjutnya untuk variabel ukuran perusahaan yang diproksikan dengan size, yang dilakukan secara efektif dan efisien oleh perusahaan akan mempengaruhi ROE secara positif. Jika terjadi kenaikan satu satuan pada size dan variabel independen lainnya dianggap konstan, maka probabilitas ROE akan naik sebesar 0.070933 satuan. Variabel DER juga berpengaruh positif terhadap ROE. Jika terjadi kenaikan satu satuan pada DER dan variabel independen lainnya dianggap konstan, maka ROE akan naik sebesar 0.0385161 satuan. Variabel CR berpengaruh negatif terhadap ROE. Jika terjadi kenaikan satu satuan pada CR dan variabel independen lain dianggap konstan, maka ROE akan turun sebesar -0.011331 satuan.. Lalu untuk variabel DR juga akan mempengaruhi ROE secara negatif. Jika terjadi kenaikan satu satuan pada DR dan variabel independen lain dianggap konstan, maka ROE akan turun sebesar -1.675496 satuan.

\section{Tabel 1 \\ Hasil Regresi}

Variable Coefficient Prob.




\begin{tabular}{lll} 
C & -0.319349 & 0.7119 \\
AKT & 0.077996 & 0.0101 \\
SIZE & 0.070933 & 0.3427 \\
DER & 0.385161 & 0.0000 \\
CR & -0.011331 & 0.5818 \\
DR & -1.675496 & 0.0000 \\
\hline \hline Adjusted R-squared & & 0.952083 \\
Prob(F-statistic) & 0.000000 \\
\hline \hline
\end{tabular}

Sumber : Hasil pengolahan data dengan Software Eviews 9.0

Nilai koefisien determinasi (Adjusted $\mathrm{R}^{2}$ ) digunakan untuk mengetahui besarnya variansi dari variabel dependen yang dapat dijelaskan oleh variabel - variabel independen yang diteliti. Hasil uji adjusted $\mathrm{R}^{2}$ untuk model analisis regresi dapat dilihat pada Tabel 4.5 di atas. Persamaan regresi linier berganda penelitian ini memiliki koefisien determinasi (Adjusted $R^{2}$ ) sebesar 0.952 atau 95,2\% yang artinya sebesar 95,2\% variabel dependen yaitu ROE dapat dijelaskan oleh variabel independen, yaitu: dalam penelitian ini adalah aktivitas rasio (TATO), ukuran perusahaan (size), stuktur modal (DER), likuiditas (CR) dan debt ratio (DR) bersama-sama terhadap probabilitas (ROE) sedangkan sisanya sebesar 4,8\% dapat dijelaskan oleh faktor-faktor lain yang tidak dimasukkan dalam penelitian ini.

Variabel aktivitas rasio diproksikan dengan total asset turnover (TATO) secara parsial berpengaruh positif dan signifikan terhadap probabilitas (ROE). Hasil ini penelitian ini sesuai dengan teori dari Syamsuddin (2009:19) yang menyatakan TATO merupakan rasio yang menunjukkan tingkat efisiensi penggunaan keseluruhan aktiva perusahaan dalam menghasilkan volume penjualan tertentu. Perusahaan manufaktur sub sektor makanan dan minuman efektif dalam penggunaan aktivanya. Semakin tinggi rasio TATO maka semakin tinggi tingkat perputaran suatu aktiva perusahaan, sehingga semakin cepat untuk menghasilkan total penjualan bersih perusahaan. Semakin efektif TATO perusahaan, maka semakin baik kinerja perusahaan yang dicapai untuk membuktikan perusahaan mampu menghasilkan laba atau tingkat keuntungan yang maksimal. Hasil penelitian ini sejalan dengan Mou Xu dan Wanrapee B. (2015) ; Arif S. (2011) ; Rizki Andriani P. et al (2015) yang menyatakan positif dan signifikan bertentangan Vironika Sari dan Budiasih (2014) ; Kamaliah et al (2009) menyatakan positif dan tidak signifikan.

Variabel ukuran perusahaan yang diproksikan dengan size berpengaruh secara positif dan tidak signifikan terhadap probabilitas (ROE). Hasil penelitian ini sesuai dengan teori Sidharta (2000) yang menyatakan ukuran perusahaan adalah skala perusahaan yang dilihat dari total aktiva perusahaan akhir tahun. Total penjualan juga dapat digunakan untuk mengukur besarnya perusahaan. Ukuran perusahaan bukan jaminan bahwa perusahaan akan memiliki kinerja yang baik yang tercermin dari laba. Ukuran perusahaan tidak berpengaruh terhadap profitabilitas. Hal ini terjadi karena pasar kurang bereaksi terhadap banyaknya informasi yang tersedia pada perusahaan-perusahaan yang berskala besar dan pada saat pengumuman laba. Selain itu bisa saja perusahaan tidak memaksimalkan aset yang ada untuk mencapai keuntungan yang diinginkan. Sehingga dapat disimpulkan ukuran perusahaan tidak dapat dijadikan salah satu tolak ukur untuk menentukan kemampuan perusahaan menghasilkan laba. Karena perusahaan yang berukuran besar belum tentu mampu menghasilkan laba yang besar dari pada perusahaan yang berukuran kecil. Hasil penelitian ini sejalan dengan Tariku N. (2016) ; Vironika S. dan Budiasih (2014) yang menyatakan positif dan tidak signifikan bertentangan dengan Mou Xu dan Wanrapee B. (2015) menyatakan negatif dan tidak signifikan. 
Variabel struktur modal (DER) secara parsial berpengaruh positif dan signifikan terhadap probabilitas (ROE). Hasil penelitian sesuai dengan teori dari Fahmi (2012:128) yang menyatakan debt equity ratio adalah ukuran yang dipakai dalam menganalisis laporan keuangan untuk memperlihatkan besarnya jaminan yang tersedia untuk kreditor. Semakin tinggi hasil DER, maka akan semakin besar kreditur meminjamkan hutang ke perusahaan. Pembelanjaan investasi perusahaan yang dilakukan dengan menggunakan hutang dapat mempengaruhi kemampuan perusahaan dalam menghasilkan laba atas modal yang dimiliki perusahaan. Rasio DER yang tinggi dapat menggambarkan bahwa perusahaan dapat beroperasi dengan hutang sebagai modalnya. Hutang usaha ini jika dipergunakan secara tepat akan dapat menghasilkan profit yang semakin meningkat pula bila dibandingkan dengan operasional dengan modalnya sendiri. Hasil penelitian ini sejalan dengan Rizki Andriani P. et al (2015) ; Ahmad Ali (2015) menyatakan positif dan signifikan bertentangan dengan Faizatur Rosyadah et al (2013) ; Vironika Sari dan Budiasih (2014) menyatakan negatif dan signifikan.

Variabel likuiditas yang diproksikan dengan current ratio secara parsial berpengaruh negatif dan tidak signifikan terhadap probabilitas (ROE). Hasil penelitian sesuai dengan teori yang disampaikan oleh Horne dan Wachowicz (2009) yang menyatakan bahwa profitabilitas berbanding terbalik dengan likuiditas. Dimana CR tidak mempengaruhi profit yang diterima perusahaan. Hal ini dapat terjadi karena perusahaan manufaktur sub sektor makanan dan minuman dalam penggunaan hutang jangka pendek dapat menempatkan dana yang besar untuk memenuhi likuiditas perusahaan, maka perusahaan dapat kehilangan kesempatan untuk mendapatkan tambahan dana karena dana yang dimiliki tidak menghasilkan keuntungan. Hal ini menunjukkan kinerja manajemen yang tidak efektif dalam memanfaatkan kekayaan perusahaan untuk memperoleh laba. Hal ini sejalan dengan Rizki Andriani P. et al (2015) ; Risfa Jenia A. (2017) menyatakan negatif dan tidak signifikan bertentangan dengan Septy Wulan S. (2017) ; Ahmad Ali (2015) menyatakan positif dan signifikan.

Variabel debt ratio (DR) secara parsial berpengaruh negatif dan signifikan terhadap probabilitas (ROE). Hasil penelitian ini sesuai dengan teori Syamsuddin (2007:30) yang menyatakan debt ratio digunakan untuk mengukur seberapa besar jumlah aktiva perusahaan dibiayai dengan total hutang. Semakin tinggi rasio ini berarti semakin besar jumlah modal pinjaman yang digunakan untuk investasi pada aktiva guna menghasilkan keuntungan bagi perusahaan peningkatan debt ratio (DR) akan meningkatkan probabilitas (ROE) meskipun peningkatan tersebut tidak signifikan atau sedikit. Semakin besar hutang yang harus ditanggung perusahaan untuk memenuhi kebutuhannya akan dana, semakin besar pula biaya yang harus dikeluarkan untuk pendanaan, baik untuk membayar biaya bunga, maupun untuk perantara keuangan. Maka semakin tinggi DR akan menyebabkan ROE semakin kecil. Akan tetapi perusahaan yang memiliki utang dalam kategori relatif tinggi cenderung dapat menurunkan tingkat profitabilitasnya. Hal ini disebabkan karena perusahaan wajib membayar bunga atas pinjaman yang dilakukan. Hal ini sejalan dengan Fawzi S. dan Jaafer M. (2011) ; Mou Xu dan Wanrapee B. (2015) menyatakan negatif dan signifikan bertentangan Tariku N. (2016) ; Slamet P. dan Ahmad D. (2017) menyatakan positif dan signifikan.

\section{KESIMPULAN}

Kesimpulan dari penelitian ini adalah TATO, size, DER, CR dan DR secara bersama - sama berpengaruh signifikan terhadap ROE pada perusahaan manufaktur pada sub sektor makanan dan minuman yang terdaftar dalam Bursa Efek Indonesia. TATO dan DER parsial berpengaruh secara positif dan signifikan, Size secara parsial berpengaruh positif dan tidak signifikan, Cr secara parsial berpengaruh negatif dan tidak signifikan dan DR secara parsial berpengaruh negatif dan signifikan ROE pada perusahaan manufaktur pada sub sektor makanan dan minuman yang terdaftar dalam Bursa Efek Indonesia. 


\section{SARAN}

Saran untuk peneliti selanjutnya, sebaiknya menambah variabel - variabel lain yang juga dapat mempengaruhi probabilitas (ROE), jumlah observasi dalam penelitian dan memperpanjang periode penelitian sehingga hasil penelitian dapat lebih tepat. Untuk para manajer perusahaan, agar mempertimbangkan faktor fundamental perusahaan yang ada pada penelitian ini mempunyai pengaruh yang signifikan terhadap probabilitas (ROE) yaitu aktivitias rasio (TATO) dan struktur modal (DER) karena perubahan aktivitias rasio (TATO) dan struktur modal (DER) mempunyai pengaruh yang positif terhadap probabilitas (ROE) sehingga memiliki potensi yang baik untuk meningkatkan laba perusahaan. Untuk investor sebaiknya memperhatikan faktor-faktor lainnya yang berpengaruh terhadap probabilitas (ROE) sebelum mengambil keputusan investasi sehingga ketika melakukan investasi tidak hanya rasio keuangan seperti aktivitas rasio (TATO), ukuran perusahaan (size), struktur modal (DER), likuiditas (CR) dan debt ratio (DR) tetapi juga rasio-rasio lainnya yang dapat mempengaruhi probabilitas (ROE) seperti Quick Ratio, Institutional Ownership dan kepemilikan manajerial agar investasi menjadi aman dengan memiliki data yang mendukung untuk berinvestasi di perusahaan tersebut.

\section{DAFTAR KEPUSTAKAAN}

Ali, Ahmad. (2015). Pengaruh Struktur Modal Terhadap Profitabilitas Pada Perusahaan Telekomunikasi. Jurnal Ilmu dan Riset Manajemen. Vol.4. No. 9.

Argananta, Risfa Jenia. (2017). Analisis Pengaruh Cr, Der dn Tato Terhadap Roe pada. Pt. Mustika Ratu Tbk. Jurnal Ilmu dan Riset Manajemen. Vol.6. No.10, 2461-0593.

Erna J. 2014. Laba Bersih INDF Melonjak 90\% jadi Rp 1,37 T. Sindonews. 30 April 2014. From https://ekbis.sindonews.com/read/859052/32/laba-bersih-indf-melonjak-90-jadi-rp137t-1398836817 diakses 2 Juli 2018 Pukul 20.30.

Erna J. 2014. Laba Bersih Ultraja Turun 26\% jadi Rp 205 M. Sindonews. 31 Oktober 2014. Form https://ekbis.sindonews.com/read/918006/32/laba-bersih-ultrajaya-turun-26-jadi-rp205m-1414749677 diakses 2 Juli 2018 Pukul 20.00.

Fahmi, Irham. (2011). Analisis Laporan Keuangan. Bandung: ALFABETA. Hal: 2

Fahmi, Irham. (2012). Analisis Laporan Keuangan. Cetakan ke-2. Bandung: ALFABETA. Hal : 128 .

Fahmi, Irham. (2014). Analisis Laporan Keuangan. Edisi 3. Bandung: ALFABETA.

Hal: 121

Fouche, J-P., Wee N.J.A.D., Roelofs K., \& Stein D.J. (2013). Recent Advances In The Brain Imaging of Social Anxiety Disorder. Human Psychopharmacology : Clinical \& Experimental; 28 (1): 102-105.doi : 10.002/hup.2281.

Kamaliah, Nasrizal A \& Lexinta K. (2009). Analisis Pengaruh Rasio Aktivitas, Leverage Keuangan, Ukuran dan Umur Perusahaan terhadap Profitabilitas Perusahaan Wholesale and Retail Trade uang Terdaftar di Bursa Efek Indonesia. Jurnal Ekonomi. Vol.17 No.3.

Munawir S.(2007). Analisa Laporan Keuangan. Yogyakarta: Liberty. Hal: 239

Munawir S. (2010). Analisis laporan keuangan. Edisi 4. Yogyakarta: Liberty.

Negasa, Tariku. (2016). The Effect of Capital Structure on Firms' Profitability. Doi: 10.20944/preprints201607.0013.v1.

Pongrangga, Rizki A., Dzulkirom \& Saifi. (2015). Pengaruh Current Ratio, Total Asset Turnover Dan Debt To Equity Ratio Terhadap ROE. Jurnal Administrasi Bisnis (JAB). Vol. 25. No. 2.

Priyanto, Slamet \& Ahmad D. (2017). Pengaruh Debt To Asset Ratio (Dar), Debt To Equity Ratio (Der), Long Term Debt To Asset Ratio (Ldar) Dan Long Term Debt To Equity Ratio 
(Lder) Terhadap Profitability (Roe) Pada Perusahaan Manufaktur Di Bursa Efek Indonesia Periode 2012-2014. Jurnal Manajemen dan Bisnis MEDIA EKONOMI. Vol. XVII. No.1.

Purnomosidi, Lukman S., Hermanto S. S\& Dzulkirom. (2014). The Influences Of Company Size, Capital Structure, Good Corporate Governance, Inflation, Interest Rate, And Exchange Rate Of Financial Performance And Valueof The Company. Interdisciplinary Journal Of Contemporary Research In Business. Vol. 5. No. 10.

Rosyadah, Faizatur, Suhadak dan Darminto. (2013). Pengaruh Struktur Modal Terhadap Profitabilitas. Universitas Brawijaya Malang. Jurnal Administrasi Bisnis. Vol.3. No.2.

Salim, Jihan. (2015). Pengaruh Leverage (Dar, Der, Dan Tier) Terhadap Roe Perusahaan Properti Dan Real Estate Yang Terdaftar Di Bursa Efek Indonesia Tahun 2010 - 2014. Perbanas Review. Vol. 1. No.1.

Sari Septy W. (2017). Pengaruh Struktur Modal, Likuiditas terhadap Profitabilitas Perusahaan Makanan dan Minuman di BEI. Jurnal Ilmu dan Riset Manajemen. Vol. 6. No.6, 2461-0593.

Sari, Vironika \& Budiasih. (2014). Pengaruh Debt To Equity Ratio, Firm Size, Inventory Turnover Dan TATO Pada Profitabilitas. E-Jurnal Akutansi Universitas Undayana 6.2, 23028556.

Sartono, Agus. (2001). Manajemen Keuangan Teori dan Aplikasi. Yogyakarta: BPEF.

Shubita, M. Fawzi \& Jaafer M. (2011). The Relationship between CapitalStructure and Profitability. International Journal of Business and Sosial Science. Vol. 3 No. 16 [Spesial Issue-August 2012].

Singapurwoko, Arif. (2011). The Impact of Financial Leverage to Profitability Study of NonFinancial Companies Listed in Indonesia Stock Exchange. EuroJournals, Inc. European Journal of Economics, Finance and Administrative Sciences. ISSN 1450-2275. Issues 32 (2011).

Sugiyarso, G. dan F. Winarni. (2005). Manajemen Keuangan (Pemahaman Laporan Keuangan, Pengelolaan Aktiva, Kewajiban dan Modal serta Pengukuran Kinerja Perusahaan). Yogyakarta: Media Pressindo. Hal : 118.

Syamsuddin, Lukman. (2007). Manajemen Keuangan Perusahaan. Konsep Aplikasi dalam:Perencanaan, Pengawasan, dan Pengambilan Keputusan. Jakarta: PT. RajaGrafindo Persada. Hal: 30.

Syamsuddin, Lukman. (2009). Manajemen Keuangan Perusahaan. Jakarta: PT. Raja Grafindo Persada. Hal: 19, 62.

Utama, Sidharta. (2000). Teori dan Riset Akuntansi Positif : Suatu Tinjauan Literatur. Jurnal Ekonomi dan Bisnis Indonesia. No. 1. Hal: 83-96.

$\mathrm{Xu}$, Mou \& Wanrapee Banchuenvijit. (2015). Factors Affecting Financial Perfomance of Firms Listed on Shanghai Stock Exchange 50. International Journal of Business and Economics. Vol.6 No.2 


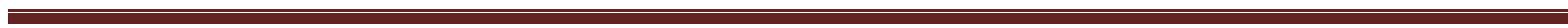
$\cdot$ 